\title{
Maten van openbare orde
}

\author{
Mr.drs. B.T.M. van der Wiel*
}

Het privaatrechtelijke begrip 'openbare orde' wordt in de heersende leer geduid als 'contextgebonden' en dus meerduidig begrip. Bovendien wordt onderscheid gemaakt tussen de nationale en internationale openbare orde. In deze bijdrage wordt een uniforme benadering van het openbareordebegrip verdedigd.

\section{Het openbareordebegrip in het interne Nederlandse recht}

In het interne Nederlandse recht heeft het begrip openbare orde twee te onderscheiden betekenissen. Enerzijds kennen wij de openbare orde als 'de normale gang van het maatschappelijk leven op een bepaalde plaats en onder de gegeven omstandigheden'. ${ }^{1}$ De openbare orde in deze zin speelt met name (maar niet uitsluitend ${ }^{2}$ ) een rol in het publiekrecht, zoals bijvoorbeeld in hoofdstuk IX en XI van de Gemeentewet over de handhaving van de openbare orde. ${ }^{3}$ Deze betekenis van het begrip openbare orde is in het kader van deze bijdrage niet relevant. Het gaat mij hier om de tweede betekenis van het begrip openbare orde: het geheel van regels en beginselen die in onze rechtsorde van fundamentele betekenis zijn. De betekenis van dit begrip openbare orde in het Nederlandse privaatrecht laat zich toelichten aan de hand van drie belangrijke toepassingen ervan: ${ }^{4}$

a. Nietig zijn rechtshandelingen die door inhoud of strekking strijden met de openbare orde (art. 3:40 lid 1 BW). Dit is het geval indien sprake is van '(...) strijd met funda-

\footnotetext{
Mr. drs. B.T.M. van der Wiel is advocaat bij Houthoff te Amsterdam.

De auteur is in de feitelijke praktijk en als cassatieadvocaat betrokken (geweest) bij procedures waarin het begrip openbare orde een rol speelt. De auteur en zijn kantoorgenoten zijn voorts betrokken geweest bij een deel van de procedures die hebben geleid tot in deze bijdrage aangehaalde uitspraken. De titel van deze bijdrage is geinspireerd op H.J. Snijders, Maten van dwingend recht, in: T. Hartlief \& C.J.J.M. Stolker (red.), Contractsvrijheid, Deventer: Kluwer 1999, p. 159-164. Deze bijdrage bouwt voort op mijn bijdrage 'Openbare orde in de internationale procespraktijk', in: R.S. Meijer e.a. (red.), Accompli (Koppenol-Laforce-bundel), Den Haag: Boom juridisch 2021, p. 313-331. Op onderdelen zijn de bijdragen identiek.

1. Aldus de gezaghebbende definitie van A-G s'Jacob in zijn conclusie (ECLI:NL:PHR:1966:AB6379) voor HR 29 november 1966, ECLI:NL:HR:1966:AB6379, NJ 1967/58 m.nt. D. van Eck.

2. Zie bijv. art. 7:231 lid 2 BW.

3. Zie over openbare orde in deze zin bijv. J.G. Brouwer, Wat is openbare orde?, NJB 2016/1561.

4. Er zijn meer toepassingen; ik noem art. 1:53 lid 2, 1:71a, 2:20, 7:902 en 10:6 BW. De betekenis van dit openbareordebegrip dat in deze bijdrage centraal staat, is niet beperkt tot het privaatrecht: zie bijv. art. 8 Grondwet.
}

mentele beginselen van de rechtsorde of met algemene belangen van fundamentele aard'.

b. De rechter dient recht van openbare orde ambtshalve buiten de grenzen van het partijdebat (art. $24 \mathrm{Rv}$ ) toe te passen, zo wordt uit art. $25 \mathrm{Rv}$ afgeleid. ${ }^{6}$ Een rechtsregel is in deze zin van openbare orde indien deze '(...) strekt ter bescherming van algemene belangen van zo fundamentele aard dat zij (ongeacht het partijdebat of de bijzondere omstandigheden van het geval) altijd door de rechter moet worden toegepast'?

c. Een arbitraal vonnis dat in strijd is met de openbare orde is vernietigbaar (art. 1065 lid 1 sub e Rv). Deze strijd kan gelegen zijn in zowel inhoud als totstandkoming van het arbitraal vonnis. Van strijd van de inhoud van een arbitraal vonnis met de openbare orde is sprake '(...) indien de inhoud of uitvoering van het arbitrale vonnis strijdt met dwingend recht van een zo fundamenteel karakter dat de naleving ervan niet door beperkingen van procesrechtelijke aard mag worden verhinderd'.

Uit de geciteerde definities van de Hoge Raad volgt dat niet snel zal mogen worden aangenomen dat een kwestie de openbare orde raakt, of wellicht beter gezegd: dat de openbare orde een kwestie raakt. Die terughoudendheid strookt met het uitgangspunt van partijautonomie. Dit beginsel houdt in dat rechtssubjecten in beginsel vrij zijn naar eigen inzicht hun rechten uit te oefenen en hun rechtspositie vorm te geven. ${ }^{9}$ In overeenstemming met deze terughoudendheid is niet alle dwingend recht van openbare orde. Instructief in dit verband

5. HR 11 december 2015, ECLI:NL:HR:2015:3568, NJ 2017/59 m.nt. Jac. Hijma (Wijnen Bouw/Muller), r.o. 3.5.1. Zie nader Asser/Sieburgh 6-III $2018 / 345$.

6. Zie over art. 24 en $25 \mathrm{Rv}$ bijv. Asser Procesrecht/Van Schaick 2 2016/98-100; H.J. Snijders, C.J.M. Klaassen \& G.J. Meijer, Nederlands burgerlijk procesrecht, Deventer: Wolters Kluwer 2017, nrs. 45 en 47; conclusie A-G De Bock 25 september 2020, ECLI:NL:PHR:2020:845, nr. 4.37 met nadere verwijzingen.

7. HR 28 januari 2011, ECLI:NL:HR:2011:BO7122, NJ 2011/167 m.nt. P. van Schilfgaarde (Staalbankiers/Elko en Van Hooven), r.o. 3.8; HR 1 juni 2018, ECLI:NL:HR:2018:818, NJ 2020/406 m.nt. H.B. Krans (Rabobank/X), r.o. 3.6. Vgl. de licht afwijkende bewoordingen in HR 21 mei 2021, ECLI:NL:HR:2021:747, NJ 2021/198, JBPr 2021/28 m.nt. G.C.C. Lewin (X/PontMeyer), r.o. 3.2.1.

8. HR 21 maart 1997, ECLI:NL:HR:1997:AA4945, NJ 1998/207 m.nt. H.J. Snijders (Eco Swiss/Benetton), r.o. 4.2; HR 12 april 2019, ECLI:NL:HR:2019:565, NJ 2020/15 m.nt. H.J. Snijders (Ecuador/Chevron), r.o. 4.3.2. Snijders is in eerstgenoemde noot sub 3a kritisch over de door de Hoge Raad gegeven definitie; die kritiek heeft de Raad er niet van weerhouden de definitie in laatstgenoemd arrest te herhalen.

9. Zie J. Neuner, Allgemeiner Teil des Bürgerlichen Rechts, München: C.H. Beck 2020, $\$ 10$ Rn. 28 e.v. en i.h.b. Rn 30. 
is de door H.J. Snijders geïntroduceerde aanduiding van recht van openbare orde als superdwingend recht. ${ }^{10}$

\section{Het openbareordebegrip: uniform of contextgebonden?}

De hiervoor genoemde toepassingen van de openbare orde hebben dus gemeen dat grote terughoudendheid moet worden betracht. Maar dat betekent nog niet dat het begrip openbare orde in de verschillende toepassingen dezelfde inhoud heeft. De vraag is hiermee of kan worden uitgegaan van een uniform begrip openbare orde, of dat het begrip openbare orde contextgebonden is, met een per context uiteenlopende betekenis.

Snijders heeft zich in een publicatie uit 1999 de vraag gesteld hoe moet worden gedacht over de onderlinge verhouding tussen de openbareordebegrippen van (onder meer ${ }^{11}$ ) de hiervoor genoemde drie toepassingen van de openbare orde. Volgens Snijders pleit veel voor vereenzelviging: de hypothese van de eenheid van wetgevingsterminologie (welke hypothese mijns inziens kan worden doorgetrokken naar de gevallen waarin de Hoge Raad wetstermen gebruikt buiten hun wettelijke toepassingsbereik), het systeem van het recht en de wetsgeschiedenis. ${ }^{12}$ Snijders' argumentatie komt mij overtuigend voor. Het standpunt van Snijders komt bovendien tegemoet aan de desiderata van rechtseenheid en hanteerbaarheid van het recht. Het begrippenpaar 'van openbare orde' en 'niet van openbare orde' impliceert één tweedeling. Het fundamentele en principiële karakter van deze tweedeling lijkt zich niet goed te verhouden met contextgebonden verschillen.

Toch valt het aannemen van te onderscheiden tweedelingen per context niet op logisch dwingende gronden uit te sluiten. In theorie is denkbaar dat de grens tussen hetgeen wel respectievelijk niet door de openbare orde wordt geraakt anders loopt al naar gelang het gaat om verschillende contexten. Zo bezien is voorstelbaar dat die grens bijvoorbeeld in het kader van art. 3:40 BW anders moet worden getrokken dan in het kader van art. $25 \mathrm{Rv}$. Snijders brengt hiertegen in dat een verschil van inhoud heel onpraktisch zou zijn. ${ }^{13}$ Dat is enerzijds juist, maar anderzijds niet dwingend en bovendien te relativeren: het (praktische) voordeel van een contextuele benadering is (juist) dat (schijnbare) tegenstrijdigheden tussen verschillende toepassingen van de openbare orde geen hoofdbrekens hoeven op te leveren: die tegenstrijdigheden kunnen aan het uiteenlopen van de context worden toegeschreven. Zo hoeft het mogelijke knellen van een systematische/unificerende benadering niet in de weg te staan aan het bereiken van oplossingen die rechtens juist voorkomen. Deze benadering, die ik hierna zal aanduiden als het contextaxioma, lijkt momenteel de

10. Snijders 1999, passim.

11. Snijders 1999, par. 4 gaat ook in op art. 7:902 BW.

12. Snijders 1999 , par. 4.

13. Snijders 1999, par. 4. heersende. ${ }^{14}$ Ook Snijders lijkt zich in de loop van de tijd tot deze opvatting bekeerd te hebben. In een publicatie uit 2014 schrijft hij: ${ }^{15}$

'Men kan (...) spreken van divergentie of zelfs inconsistentie van de wetgeving inzake de openbare orde. De wettekst zelf duidt daar niet op, maar in de rechtspraak wordt de term openbare orde verschillend uitgelegd naar gelang de context waarin deze fungeert. Reeds de parlementaire geschiedenis van de betrokken wettelijke regelingen over de openbare orde laat zien dat het begrip telkens vraagt om een contextgebonden uitleg en daarin voorziet de rechtspraak dan ook mede in het licht van die verschillende wetshistorische perspectieven.'

Kennelijk leest Snijders de relevante parlementaire geschiedenis in 2014 anders dan in 1999, toen hij deze nog inriep ten faveure van vereenzelviging van verschillende toepassingen van openbare orde. Helaas bevat zijn bijdrage uit 1999 in zoverre geen verwijzingen, en gaat Snijders in 2014 alleen in op de parlementaire geschiedenis van art. 2:20 BW. Hij geeft daarbij het volgende (uit 1987 daterende) citaat van de Minister van Justitie: ${ }^{16}$

'Het begrip "openbare orde" ontleent zijn vaagheid vooral hieraan dat het in het ene rechtsgebied een andere betekenis heeft dan in het andere. In het privaatrecht dient het als machtsmiddel in de hand van de rechter om te kunnen ingrijpen tegen misbruik van vrijheden en bevoegdheden. Sinds jaar en dag is de rechter zuinig in het gebruik van dit wapen. Al deze in de rechtspraak vastgelegde lijnen bieden hetzelfde perspectief en voeden zo het vertrouwen dat de rechter een beperkte uitleg zal blijven geven.'

Zelf lees ik in dit citaat geen overtuigende steun voor het contextaxioma. De minister differentieert slechts per rechtsgebied. Denkbaar is (het blijft impliciet) dat hij hiermee duidt op het in paragraaf 1 gemaakte onderscheid tussen het openbareordebegrip dat het onderwerp vormt van deze bijdrage en een daarvan geheel losstaand openbareordebegrip. Belangrijker is dat de minister voor het privaatrecht (juist) met een contextoverstijgende duiding komt ('machtsmiddel tegen misbruik'). Of die duiding zelf de meest gelukkige is, laat ik nu even daar; waar het mij om gaat, is dat zij eerder tegen dan vóór contextgebonden differentiatie pleit. Nadere analyse is noodzakelijk om te bepalen of het contextaxioma steun vindt in het geldende recht. Die analyse zal ik hierna beproeven, maar niet dan nadat ik op een tweede complicatie heb gewezen.

14. Zie bijv. Snijders, in: GS Burgerlijke rechtsvordering, art. 1054, aant. 2.7 en H.J. Snijders, Openbare orde, rechtspersonen en mensenrechten, NJB 2014/1174, par. 1, alsmede De Loos-Wijker, in: GS Vermogensrecht, titel 3.2, aant. 19.2.1 met nadere verwijzingen, waaraan valt toe te voegen S. Stuij, Iura novit curia en buitenlands recht (diss. Rotterdam; Burgerlijk Proces \& Praktijk nr. XX), Deventer: Wolters Kluwer 2021, nr. 27.

15. Snijders 2014, par. 1.

16. Kamerstukken I 1986/87, 17476, nr. 57b, sub 9 (MvA I). 


\section{Maandblad \\ Vermogensrecht}

Het supranationale en het Nederlandse internationale procesrecht kennen verschillende bepalingen waarin de openbare orde als drempel fungeert. Via deze sluiswerking ${ }^{17}$ van de openbare orde worden onaanvaardbare regels van buitenlands recht (zie bijv. art. 10:6 BW), onaanvaardbare buitenlandse rechterlijke uitspraken (zie bijv. art. 45 lid 1 sub a Brussel I bisVerordening) en onaanvaardbare buitenlandse arbitrale vonnissen (zie bijv. art. $1075 \mathrm{Rv}$ ) buiten de deur gehouden. De sluis is breed: import wordt in beginsel gefaciliteerd. ${ }^{18}$ De openbare orde fungeert als exceptie en is als zodanig niet meer dan een veiligheidsklep, ${ }^{19}$ om nog een andere niet-originele metafoor te gebruiken. Import wordt pas onaanvaardbaar geacht indien sprake is van onverenigbaarheid met de beginselen en waarden die in onze rechtsorde voor fundamenteel worden gehouden, aldus de in het kader van het Nederlandse internationale procesrecht ingeburgerde algemene formule voor (strijd met) de openbare orde, ${ }^{20}$ die aansluit op de voormelde formules die de Hoge Raad heeft ontwikkeld in het kader van art. 3:40 lid 1BW, art. $25 \mathrm{Rv}$ en art. 1065 lid 1 sub e Rv.

Weliswaar sluiten de formuleringen bij elkaar aan, heersende leer is evenwel dat onderscheid moet worden gemaakt tussen het openbareordebegrip van het interne recht en het openbareordebegrip in het internationaal privaatrecht: de zogenaamde 'internationale openbare orde'. Volgens de heersende leer moet dit laatste begrip nog terughoudender worden ingevuld dan het openbareordebegrip van het interne recht. ${ }^{21}$ Ziehier het differentiatieaxioma, dat kan worden gezien als een toepassing van het contextaxioma.

17. H.U. Jessurun d'Oliveira, Openbare orde en rechtsvergelijking, in: H.U. Jessurun d'Oliveira e.a. (red.), 't Exempel dwinght (Kisch-bundel), Zwolle: W.E.J. Tjeenk Willink 1975, p. 239, merkt op: 'Als de openbare orde over de akkers van het ipr loopt, is de beeldspraak niet van de lucht (...). Het beeld van de sluis is in dit verband niet origineel: zie Asser/Vonken 10-I 2018/515. Zie voorts over de metaforiek in dit verband H.U. Jessurun d'Oliveira, Inlijving van de openbare orde van de EU in die van de lidstaten?, NJB 2015/1734, par. 1 met nadere verwijzingen.

18. Vandaar dat hier ook wel wordt gesproken van openbare orde in negatieve zin. Zie bijv. Asser/Vonken 10-I 2018/488.

19. Zie bijv. W. Wurmnest, Ordre public (Public Policy), in: S. Leible, General Principles of European Private International Law, Alphen aan den Rijn: Kluwer Law International 2016, p. 305; L. Strikwerda \& S.J. Schaafsma, Inleiding tot het Nederlandse internationaal privaatrecht, Deventer: Wolters Kluwer 2019, nr. 132.

20. Zie bijv. Asser/Vonken 10-I 2018/485 en 563; Strikwerda \& Schaafsma 2019/131, 269 en 290; Advies Staatscommissie IPR, nr. 77 (Parl. Gesch. Boek 10 BW, par. II.8.2).

21. Zie bijv. Parl. Gesch. Boek 10 BW, par. II.8.3 (MvT bij art. 10:6 BW); Asser/Kramer \& Verhagen 10-III 2015/948; Snijders, in: GS Burgerlijke rechtsvordering, art. 1054, aant. 2.7, art. 1063, aant. 1.2, art. 1065, aant. 7 en art. 1076, aant. 8; De Loos-Wijker, in: GS Vermogensrecht, titel 3.2, aant. 19.2.1 met nadere verwijzingen; Asser/Vonken 10-I 2018/398 en 487; Strikwerda \& Schaafsma 2019/131. Aldus ook het Duitse recht (zie bijv. Zöller/Geimer 2018, \$328 ZPO, Rn. 211) en het Belgische recht (zie bijv. A. Hansebout, art. 21 Wetboek van internationaal privaatrecht (WIPR), aant. 1, in: I. Couwenberg e.a. (red.), Duiding internationaal privaatrecht, Gent: Larcier 2014).
Paradoxaal genoeg wordt het begrip internationale openbare orde primair nationaal ingevuld. ${ }^{22}$ Hierom wordt bijvoorbeeld gesproken van de Nederlandse internationale openbare orde, die dus kan verschillen van bijvoorbeeld de Duitse internationale openbare orde. De nationale invullingen van het begrip internationale openbare orde zijn deels wel eenvormig, namelijk voor zover zij worden bepaald door supranationaal recht. ${ }^{23}$

Het is niet eenvoudig meer vat te krijgen op de maatstaf van de openbare orde dan de hiervoor aangehaalde algemene formules geven, ${ }^{24}$ en het contextaxioma en het differentiatieaxioma maken het er niet makkelijker op. Hierna zal ik een poging wagen om inhoud en betekenis van het openbareordebegrip nader te omlijnen. Daarbij zullen het contextaxioma en het differentiatieaxioma aan een kritisch onderzoek worden onderworpen. Allereerst ga ik nader in op het openbareordebegrip zoals dat in de interne Nederlandse context wordt gebruikt (par. 3 en 4). Vervolgens zal ik ingaan op de grenzen die de openbare orde stelt aan de toepassing van buitenlands recht door de Nederlandse rechter (par. 5), en aan de erkenning van buitenlandse rechterlijke en arbitrale uitspraken (par. 6 en 7$).{ }^{25}$ Ik sluit af met een evaluatie (par. 8).

\section{Uniform of contextgebonden? Art. 3:40 lid 1 BW en art. $25 \mathrm{Rv}$}

Wanneer art. 3:40 lid 1, art. 25 en art. 1065 lid 1 sub e Rv als toepassingen van de openbare orde worden vergeleken, rijst als gezegd de vraag in hoeverre zij met elkaar in verband staan. Houdt de verwantschap op bij het gegeven dat het om strenge criteria gaat, die moeten worden ingevuld met behulp van in onze rechtsorde fundamenteel geachte noties? Hebben bepaalde regels, beginselen, belangen en waarden in de ene context een openbareordestatus die zij in een andere context ontberen, zodat het bij de openbare orde per context gaat om wezenlijk

22. Zie bijv. T. Corthaut, EU ordre public (diss. Leuven), Alphen aan den Rijn: Kluwer Law International 2012, nr. I-23; Asser/Vonken 10-I $2018 / 398$ en 487.

23. Zie bijv. Asser/Vonken 10-I 2018/505-518, mede (in het kader van het conflictenrecht) over de vraag of het niet juister is het desbetreffende supranationale recht rechtstreeks te laten werken in plaats van via het medium van de openbare orde.

24. De rechtswetenschap worstelt al enige tijd met dit probleem. Zo verzuchtte Friedrich Carl von Savigny, System des heutigen Römischen Rechts. Achter Band, Berlijn: Veit 1849, p. 32, hierover in het kader van de uitzonderingen op de toepassing van het door het conflictenrecht aangewezen recht dat ' $(. .$.$) deren Gränzen festzustellen vielleicht die schwie-$ rigste Aufgabe in dieser ganzen Lehre sein mag'. Dit citaat heeft nog weinig aan actualiteitswaarde ingeboet, getuige bijv. de noot van H.B. Krans, sub 8-9, onder HR 1 juni 2018, ECLI:NL:HR:2018:818, NJ 2020/406 (Rabobank/X).

25. De gedachte dat de openbare orde in het kader van het conflictenrecht naast een begrenzing aan de toepassing van buitenlands recht ('negatieve werking' van de openbare orde) ook de grondslag vormt voor het 'voordringen' van bepaalde regels van de lex fori onafhankelijk van de toepasselijkheid van dat recht ('positieve werking' van de openbare orde), lijkt veelal als achterhaald te worden beschouwd (zie Advies Staatscommissie IPR, nr. 86 (Parl. Gesch. Boek 10 BW, par. II.8.2); Wurmnest 2016, p. 314-315; Asser/Vonken 10-I 2018/488-489; Strikwerda \& Schaafsma $2019 / 133)$, zodat ik de figuur van de positieve werking onbesproken laat. 
afwijkende normen ${ }^{26}$ Of prevaleert de rechtseenheid boven het contextaxioma en kan worden uitgegaan van een uniform openbareordebegrip?

Allereerst onderzoek ik deze vraag aan de hand van de verschijningsvormen nietigheid van rechtshandelingen op grond van art. 3:40 lid $1 \mathrm{BW}$ en ambtshalve toepassing van rechtsregels buiten de grenzen van art. $24 \mathrm{Rv}$ op grond van art. $25 \mathrm{Rv}$ (zoals die bepaling in de context van de openbare orde wordt geïnterpreteerd). Zoals hiervoor al aan de orde kwam (zie par. 2), is het vanuit het oogpunt van rechtseenheid wenselijk dat als een rechtshandeling nietig is wegens strijd met de openbare orde in de zin van art. 3:40 lid $1 \mathrm{BW}$, de rechter verplicht is de betreffende norm steeds ambtshalve bij zijn beslissing te betrekken, ook buiten de grenzen van art. $24 \mathrm{Rv} .{ }^{27}$ En vanuit datzelfde oogpunt van rechtseenheid is ook het omgekeerde wenselijk: als sprake is van nietigheid op een grond die niet van openbare orde is, zou het de rechter verboden moeten zijn de betreffende norm buiten de door art. $24 \mathrm{Rv}$ gestelde grenzen toe te passen.

Er is wat mij betreft geen goede reden te bedenken waarom de openbare orde in de twee voornoemde contexten niet geheel eenvormig zou kunnen worden uitgelegd en toegepast. Hoe dit uitpakt, illustreer ik met twee voorbeelden. Beide voorbeelden gaan in overeenstemming met het voorafgaande uit van de volgende regel: wanneer een overeenkomst nietig is wegens strijd met de openbare orde (art. 3:40 lid 1 BW), moet de rechter dit zo nodig ambtshalve en buiten de door het partijdebat (art. $24 \mathrm{Rv}$ ) bepaalde grenzen aan zijn beslissing ten grondslag leggen. ${ }^{28}$ Een eerste - kras - voorbeeld is een overeenkomst die strekt tot slavernij. Een dergelijke overeenkomst is op grond van art. 3:40 lid 1 BW nietig en rechters zullen deze nietigheid ambtshalve moeten betrekken bij de beoordeling van hun voorgelegde vorderingen. Het tweede voorbeeld is wat subtieler. Kostenverhaal door de overheid behoeft een wettelijke grondslag. Een contractueel verhaalsrecht van de overheid dat wettelijke grondslag ontbeert, is wegens strijd met de openbare orde nietig op grond van art. 3:40 lid 1 BW. ${ }^{29}$ Als dit verweer tegen een dergelijke contractuele verhaalsvordering niet wordt gevoerd, zal de rechter deze nietig-

26. Vgl. over een verschijningsvorm van dit fenomeen de conclusie van A-G Huydecoper (ECLI:NL:PHR:2010:BO1979), sub 13, voor HR 17 december 2010, ECLI:NL:HR:2010:BO1979, NJ 2011/8 (Van Nieuwburg c.s./TMF c.s.).

27. Maar binnen die van art. 23 Rv. Zie bijv. HR 9 juli 2021, ECLI:NL:HR: 2021:1113, r.o. 3.4. Terzijde merk ik op dat bepaalde normen van Europees recht als recht van openbare orde moeten worden behandeld. Dit punt laat ik verder rusten. Zie hierover bijv. H.J. Snijders in zijn noot onder HR 8 november 2019, ECLI:NL:HR:2019:1731, NJ 2020/305 (Intermaris/X) en A.S. Hartkamp, Ambtshalve toepassing in het Unierecht en het Nederlandse privaatrecht, in: R. de Bock e.a. (red.), Voor Daan Asser. Procesrechtelijke desiderata voor zijn 75ste verjaardag (Asser-bundel), Deventer: Wolters Kluwer 2020, p. 131-145, en vele eerdere geschriften hierover van deze auteurs.

28. Aldus Asser/Sieburgh 6-III 2018/347g.

29. Zie bijv. HR 5 december 2014, ECLI:NL:HR:2014:3532, NJ 2016/159 m.nt. S.D. Lindenbergh (Michielse/Gem. Reusel-De Mierden), r.o. 3.4.2. heid ambtshalve en buiten de grenzen van art. $24 \mathrm{Rv}$ bij de beoordeling moeten betrekken.

De werkingen van de openbare orde in de context van art. 3:40 lid $1 \mathrm{BW}$ en art. $24 \mathrm{Rv}$ lopen in de hiervoor uiteengezette visie parallel. Deze op rechtseenheid geënte benadering lijkt mij tot bevredigende en goed navolgbare resultaten te leiden. Ik zie dan ook geen goede grond om hier met toepassing van het contextaxioma tot een genuanceerdere oplossing te komen. Het contextaxioma doet in deze context (dan ook) geen opgeld.

\section{Uniform of contextgebonden? Art. 3:40 lid $1 \mathrm{BW}$ en art. 1065 lid 1 sub e Rv}

Kan deze benadering worden doorgetrokken naar het openbareordebegrip van art. 1065 lid 1 sub e Rv? Dat zou betekenen dat miskenning van recht van openbare orde door arbiters, in het bijzonder door veroordeling tot nakoming van een wegens strijd met de openbare orde nietige overeenkomst, een arbitraal vonnis oplevert dat reeds op die grond aan vernietiging blootstaat. Dit heeft de aantrekkelijkheid dat het de consistentie van het interne privaatrechtelijke openbareordebegrip in belangrijke mate zou bevorderen. Rechtspraak en literatuur bieden ook stevige steun voor deze gedachte. Ten eerste heeft de Hoge Raad in de hiervoor (zie par. 1, sub c) aangehaalde arresten Eco Swiss/Benetton en Ecuador/Chevron geoordeeld dat een arbitraal vonnis op grond van art. 1065 lid 1 sub $3 \mathrm{Rv}$ kan worden vernietigd indien 'inhoud of uitvoering van het vonnis' strijdt met de openbare orde. ${ }^{30}$ Ten tweede impliceert de Hoge Raad in de prejudiciële beslissing Intermaris/X dat de exequaturrechter op grond van art. 1063 lid 1 jo. art. 1065 lid 1 sub e $\mathrm{Rv}$ moet onderzoeken of '(...) een contractueel beding dat de grondslag vormt voor de in het arbitrale vonnis vastgestelde vordering in strijd is met nationale voorschriften van openbare orde'. ${ }^{31}$ En ten derde stelt Snijders onomwonden dat ' (...) arbiters (...) gehouden zijn (...) bepalingen van openbare orde toe te passen (...). Doen zij dit niet dan is hun beslissing vernietigbaar op grond van art. 1065 lid 1 aanhef en sub e Rv. ${ }^{32}$

Toch is op dit punt een andere opvatting denkbaar, die ertoe leidt dat een arbitrale veroordeling tot nakoming van een overeenkomst die strijdig is met de openbare orde (op welk casustype ik mijn betoog toespits) niet steeds tot vernietigbaarheid van het arbitrale vonnis op grond van art. 1065 lid 1 aanhef en sub e Rv leidt. ${ }^{33}$ De gedachte dat niet alle recht van openbare orde van een zodanig gewicht is dat een arbitraal vonnis waar-

30. Zie noot 8 .

31. HR 8 november 2019, ECLI:NL:HR:2019:1731, NJ 2020/305 m.nt. H.J. Snijders (Intermaris/X), r.o. 2.5.3 jo. r.o. 2.5.2 en 2.5.5.

32. Snijders, in: GS Burgerlijke rechtsvordering, art. 1054, aant. 2.2. Dit lijkt ook de lijn te zijn van de Privy Council in zijn recente uitspraak inzake Betamax v STC (Privy Council 14 juni 2021, [2021] UKPC 14).

33. Een dienovereenkomstig standpunt lag voor in het cassatieberoep dat leidde tot HR 16 juli 2021, ECLI:NL:HR:2021:1171, RvdW 2021/818 (Wells/Bariven). De Hoge Raad heeft deze zaak evenwel op een andere grond zelf afgedaan, zodat hij dit punt onbesproken kon laten. 
in dit recht wordt miskend reeds daarom vernietigbaar is wegens strijd met de openbare orde, strookt met de in de rechtspraak getrokken lijn dat de openbareordemaatstaf bij toetsing van zowel de inhoud als de totstandkoming ${ }^{34}$ van arbitrale vonnissen met terughoudendheid moet worden toegepast. ${ }^{35}$

De hiervoor geschetste opvatting kan op twee wijzen worden ingepast. Ten eerste kan een fundering van deze opvatting worden gezocht in het contextaxioma. De openbare orde waaraan de geldigheid van rechtshandelingen wordt getoetst, heeft in die visie een andere (ruimere) inhoud dan de (engere, minder snel tot rechtsgevolg leidende) openbare orde waaraan de geldigheid van arbitrale vonnissen wordt getoetst.

Een tweede wijze waarop de opvatting dat niet alle recht van openbare orde van een zodanig gewicht is dat een arbitraal vonnis waarin dit recht wordt miskend reeds daarom vernietigbaar is wegens strijd met de openbare orde, kan worden ingepast, hangt samen met het inzicht dat de objecten waarop de hiervoor besproken toepassingen van de openbare orde zien, verschillen. Dit verschil in toetsingsobject wordt duidelijk indien art. 3:40 lid 1 BW en art. 1065 lid 1 sub e Rv tegenover elkaar worden gezet. Bij de eerste bepaling gaat het om het voorkomen van de gelding van een rechtshandeling. Hierbij is het toetsingsobject de rechtshandeling. Bij de tweede bepaling gaat het om het voorkomen van de gelding van een arbitraal vonnis waarin de rechtshandeling is beoordeeld. Hierbij is het toetsingsobject het arbitrale vonnis, en dus niet (rechtstreeks) de rechtshandeling die in dat vonnis beoordeeld is. Met de toetsingsobjecten lopen ook de rechtsgevolgen van toetsing uiteen: geldigheid dan wel nietigheid van een overeenkomst respectievelijk arbitraal vonnis. Dit uiteenlopen van toetsingsobjecten en rechtsgevolgen maakt dat ook uitgaande van een uniform openbareordebegrip niet per se tot gelijklopende toetsingsresultaten moet worden gekomen. Een nietige overeenkomst leidt niet per se tot nietigheid van een arbitraal vonnis waarin deze overeenkomst toch wordt gehonoreerd, omdat gelding van een overeenkomst iets anders is dan gelding van een arbitraal vonnis. Daaraan kan vanuit het oogpunt van de openbare orde dan ook een te onderscheiden betekenis worden toegekend, zonder dat dit aanvaarding van een contextgebonden inhoud van het begrip openbare orde vergt.

Het voordeel van deze benadering in het kader van de vernietiging van arbitrale vonnissen is dat kan worden uitgegaan van een uniform openbareordebegrip zonder dat de terughoudendheid wordt losgelaten die bij het toetsen van arbitrale

34. Behoudens wanneer sprake is van schending van hoor en wederhoor. Zie de in de volgende noot genoemde arresten.

35. HR 17 januari 2003, ECLI:NL:HR:2003:AE9395, NJ 2004/384 m.nt. H.J. Snijders (IMS/Modsaf-IR), r.o. 3.3; HR 25 mei 2007, ECLI:NL:HR:2007:BA2495, NJ 2007/294 (Spaanderman/Anova), r.o. 3.5; HR 24 april 2009, ECLI:NL:HR:2009:BH3137, NJ 2010/171 m.nt. H.J. Snijders (IMS/Modsaf), r.o. 4.3.1; HR 4 december 2020, ECLI:NL:HR:2020:1952 (Russische Federatie/HVY), r.o. 3.3.1. vonnissen aan de openbare orde in acht moet worden genomen.

De vraag of een arbitraal vonnis waarin de nietigheid van een rechtshandeling wegens strijd met de openbare orde is miskend, steeds en reeds daarom in strijd met de openbare orde moet worden geacht, zoals Intermaris/X en Snijders (zie par. 2) suggereren, zou ik in het licht van het voorafgaande ontkennend willen beantwoorden. Ik denk dat dit mogelijk is zonder het contextaxioma te aanvaarden. Hoe dit uitpakt, illustreer ik weer aan de hand van de twee hiervoor gegeven voorbeelden. Ik begin weer bij het meest krasse en dus simpele voorbeeld. Dat een arbitraal vonnis waarin een tot slavernij strekkende overeenkomst wordt gehonoreerd reeds daarom nietig is, behoeft weinig betoog. Niet alleen (het gelden van) de overeenkomst zelf is in strijd met de openbare orde, ook (het gelden van) een arbitraal vonnis waarin deze overeenkomst wordt erkend.

Bij een arbitraal vonnis waarin een vordering van een overheid tot contractueel kostenverhaal zonder wettelijke grondslag wordt toegewezen, ligt de zaak naar mijn mening anders. Dat de desbetreffende overeenkomst nietig is, staat buiten kijf. Ik zou evenwel menen dat het te ver gaat een vonnis dat deze overeenkomst erkent reeds daarom vernietigbaar te achten op grond van art. 1065 lid 1 sub e Rv. Ik zou willen verdedigen dat de geldigheid van een dergelijk vonnis niet per se in strijd is met de openbare orde, maar afhangt van de verdere omstandigheden van het geval. Zo lijkt mij verschil te maken of een betoog dat het contractuele kostenverhaal in strijd was met de openbare orde begrijpelijkerwijs (de strijd met de openbare orde was niet evident en er waren pleitbare tegenargumenten), maar op de keper beschouwd ten onrechte door arbiters is verworpen, dan wel over de strijd van het kostenverhaal met de openbare orde geen redelijke twijfel mogelijk is, maar arbiters hier kennelijk willens en wetens aan voorbij zijn gegaan. In dit laatste geval raakt niet alleen de overeenkomst, maar ook het die overeenkomst erkennende vonnis de openbare orde. In het eerste geval is eerder sprake van een 'vaktechnisch ongeluk' dat onvoldoende grond biedt tot vernietigbaarheid van het arbitrale vonnis.

Het antwoord op de vraag of een arbitraal vonnis waarin de nietigheid van een rechtshandeling wegens strijd met de openbare orde is miskend in strijd met de openbare orde moet worden geacht, is naar mijn mening derhalve: soms wel, soms niet. In een deel van de gevallen is het miskennen van de openbare orde door arbiters in een arbitraal vonnis niet zo ernstig dat het gelden van dit vonnis zélf in strijd met de openbare orde is. En in een ander deel van de gevallen is dit wel zo.

Dit impliceert dat binnen het openbareordebegrip twee subcategorieën kunnen worden onderkend. Enerzijds zijn er normen van openbare orde die maken dat een arbitraal vonnis waarin een vordering wordt toegewezen die is gebaseerd op een met een dergelijke regel strijdige en dus op grond van 


\section{Maandblad}

art. 3:40 lid $1 \mathrm{BW}$ nietige overeenkomst reeds op die grond vernietigbaar is. Dit doet zich voor bij het hiervoor gegeven voorbeeld van een overeenkomst tot slavernij. Anderzijds zijn er normen van openbare orde waarvan zodanige miskenning in een arbitraal vonnis nog niet maken dat dit vonnis reeds op die grond vernietigbaar is. Dit doet zich voor bij het hiervoor gegeven voorbeeld van kostenverhaal door de overheid. Zo bezien is het recht van openbare orde deels van een zodanig gewicht dat een arbitraal vonnis waarin dit recht wordt miskend reeds daarom ook zelf in strijd is met de openbare orde, terwijl dit voor andere regels van openbare orde niet het geval is. Ik gebruik hierna voor deze twee 'maten' van openbare orde de begrippen absolute respectievelijk relatieve openbare orde. Hier ligt een parallel met het hierna in het kader van het conflictenrecht (zie par. 5) nog te bespreken onderscheid tussen het binnen- en het buitengrenscriterium. Deze benadering laat zich rijmen met de beslissing Intermaris/X door deze te interpreteren als betreffende een geval van absolute openbare orde: de eisen van het EU-recht lieten de Hoge Raad wellicht ook geen andere keuze.

Kan het mogelijke uiteenlopen van toetsingsresultaat ten aanzien van overeenkomst respectievelijk arbitraal vonnis niet beter worden verklaard door het contextaxioma? Ik denk het niet. Dit uiteenlopen wordt in mijn visie niet veroorzaakt door het feit dat de openbare orde in de ene context strenger is dan in de andere, maar doordat vanuit het perspectief van de (uniform op te vatten) openbare orde het ene nu eenmaal minder erg is dan het andere. En gelding van een overeenkomst is iets anders dan gelding van een arbitraal vonnis.

In deze benadering is ook de hiervoor al genoemde vaste rechtspraak dat de vernietigingsgrond 'openbare orde' ten aanzien van arbitrale vonnissen met terughoudendheid moet worden toegepast, niet meer problematisch. Snijders heeft deze rechtspraak bekritiseerd met de stelling dat aldus wordt miskend dat het van tweeën een is: er is strijd met de openbare orde, of dat is niet zo. ${ }^{36}$ Dat laatste is waar, maar doet niet af aan het gegeven waaraan deze rechtspraak naar mijn opvatting uitdrukking geeft: het strijden van een in arbitrage gehonoreerde overeenkomst met de openbare orde hoeft niet steeds te leiden tot nietigheid van dat arbitrale vonnis. Dat laatste is alleen het geval indien sprake is van strijd met wat ik hiervoor de absolute openbare orde heb genoemd. Is de in arbitrage gehonoreerde overeenkomst 'slechts' in strijd met hetgeen ik hiervoor de relatieve openbare orde heb genoemd, dan hangt het lot van het arbitrale vonnis af van de omstandigheden van het geval. Dat inhoudelijke strijd van een arbitraal vonnis met recht van openbare orde niet steeds tot vernietiging van dit vonnis hoeft te leiden, strookt met het uitgangspunt dat een effectieve arbitrale rechtspleging vergt dat alleen in sprekende gevallen tot

36. H.J. Snijders in zijn noot, sub 8, onder HR 17 januari 2003, ECLI:NL:HR:2003:AE9395, NJ 2004/384 (IMS/Modsaf-IR). Zie hierover meer recent par. 4.20 e.v. van de conclusie van A-G De Bock van 11 december 2020, ECLI:NL:PHR:2020:1176 voor HR 16 juli 2021, ECLI:NL:HR:2021:1171, RvdW 2021/818 (Wells/Bariven). vernietiging van arbitrale vonnissen dient te worden overgegaan. ${ }^{37}$

De voorafgaande beschouwingen bieden ruimte om afstand te nemen van het contextaxioma ten faveure van een uniform openbareordebegrip met twee subcategorieën: absolute en relatieve openbare orde. Ruimte en noodzaak voor deze twee subcategorieën volgen uit het gegeven dat niet voor ieder arbitraal vonnis dat veroordeelt tot nakoming van een wegens strijd met de openbare orde nietige overeenkomst geldt dat de gelding ervan in strijd is met de openbare orde. Dat laatste is alleen het geval indien de nietigheidsgrond die de overeenkomst treft er een is van absolute openbare orde. In die gevallen - naast de hiervoor behandelde overeenkomst tot slavernij kan worden gedacht aan overeenkomsten die het internationaal publiekrecht raken, zoals handel in verboden wapens heeft de desbetreffende norm een zodanig fundamenteel karakter dat arbiters deze niet alleen ambtshalve moeten toepassen, maar dat bij gebreke hiervan het arbitrale vonnis reeds daarom vernietigbaar is, omdat gelding van een dergelijk arbitraal vonnis onaanvaardbaar is. Is de norm die de overeenkomst treft er een van relatieve openbare orde, dan geldt weliswaar dat arbiters deze norm ambtshalve dienen toe te passen, maar leidt een verzuim ter zake niet reeds en steeds daarom tot vernietigbaarheid van het desbetreffende arbitrale vonnis. Gelding van een dergelijk vonnis is namelijk niet per se onaanvaardbaar; voor die conclusie is meer nodig, namelijk dat daarin een norm van absolute openbare orde is miskend. Als eenmaal wordt aangenomen dat gelding van een arbitraal vonnis strijdt met de openbare orde, is er voor dat vonnis uiteraard 'geen redding meer'. 38

De hiervoor uiteengezette benadering leidt tot een uniform intern privaatrechtelijk openbareordebegrip met twee subcategorieën. De voordelen van uniformiteit kwamen hiervoor ook al aan de orde. $\mathrm{Bij}$ de navolgende bespreking van enkele belangrijke toepassingen van de openbareordemaatstaf in de internationale procespraktijk zal nog een voordeel van de hiervoor voorgestelde benadering blijken, namelijk dat ook het differentiatieaxioma kan worden gemist, zodat ook in zoverre tot een uniform openbareordebegrip kan worden gekomen.

\section{Grenzen aan toepassing van buitenlands recht}

Art. 10:6 BW bepaalt dat vreemd recht niet wordt toegepast voor zover die toepassing kennelijk onverenigbaar is met de openbare orde. Deze regel strookt met dienovereenkomstige supranationale regelingen. Zo bepalen art. 21 Rome I-Verordening en art. 26 Rome II-Verordening dat toepassing van een bepaling van het door deze verordening aangewezen recht slechts terzijde kan worden gesteld indien deze toepassing kennelijk onverenigbaar is met de openbare orde van het land

37. Zie bijv. de conclusie van A-G Wesseling-van Gent van 3 september 2021, ECLI:NL:PHR:2021:796, par. 2.6 en de in noot 13 daarvan aangehaalde rechtspraak.

38. Aldus H.J. Snijders in zijn noot, sub 8, onder HR 17 januari 2003 ECLI:NL:HR:2003:AE9395, NJ 2004/384 (IMS/Modsaf-IR). 


\section{Maandblad \\ Vermogensrecht}

van de rechter. Om de omvang van deze bijdrage enigszins aanvaardbaar te houden, beperk ik mij in deze paragraaf tot art. 10:6 BW. Het hierna betoogde is mijns inziens van overeenkomstige toepassing op het openbareordebegrip van het supranationale conflictenrecht, nu dit de Nederlandse rechter, net als art. 10:6 BW, verwijst naar zijn eigen 'internationale openbare orde' (zie par. 2).

De geadresseerde van art. 10:6 BW is de Nederlandse rechter die op grond van een conflictenrechtelijke verwijzingsregel buitenlands recht dient toe te passen. De formulering van art. 10:6 BW scherpt hem in dat hij hier ambtshalve een taak heeft. Art. 10:6 BW heeft niet alleen betrekking op de openbare orde, maar is dus ook zelf van openbare orde in de zin van art. $25 \mathrm{Rv}$ (waarover par. 3 hiervoor). ${ }^{39}$ De rechter zal art. 10:6 $\mathrm{BW}$ daarom in beginsel ${ }^{40}$ ook buiten de door art. $24 \mathrm{Rv}$ gestelde grenzen moeten toepassen.

Art. 10:6 BW eist dat van kennelijke onverenigbaarheid met de openbare orde sprake moet zijn om een buitenlandse regel buiten toepassing te laten. Deze eis accentueert dat art. 10:6 BW met terughoudendheid moet worden toegepast. Dit gebruik van de term 'kennelijk' strookt met hetgeen in verdragen, EU-verordeningen en buitenlandse wetgeving gebruikelijk is. ${ }^{41}$ De kennelijkheidseis moedigt de rechter aan terughoudend te zijn bij het oordeel dat sprake is van strijd met de openbare orde. ${ }^{42}$ Voor die aanmoediging bestaat goede grond: de neiging om onder de vlag van de openbare orde in te grijpen indien een minder wenselijk geachte uitkomst dreigt, is wijdverbreid en heeft een lange historie. ${ }^{43}$ Aan deze neiging moet weerstand worden geboden: uitgangspunt van het conflictenrecht is immers respect voor het toepasselijke buitenlandse recht. ${ }^{44}$ Aan dit uitgangspunt kan mede recht worden gedaan door hoge motiveringseisen te stellen aan het oordeel dat toepassing van buitenlands recht kennelijk in strijd is met de

39. Stuij 2021/57.

40. Zie de terechte relativering in verband met een in voorkomende gevallen bestaande mogelijkheid van afstand van een fundamenteel recht Asser/ Vonken 10-I 2018/500. Zo kan afstand worden gedaan van het recht op toegang tot de overheidsrechter, welk recht als van openbare orde kan worden aangemerkt.

41. Wurmnest 2016, p. 306; Asser/Vonken 10-I 2018/498; Strikwerda \& Schaafsma 2019/132; Vonken, in: T\&C BW, art. 10:6, aant. 2c. Zie bijv. art. 21 Rome I-Verordening en art. 26 Rome II-Verordening, het Belgische art. 21 WIPR ('kennelijk onverenigbaar met de openbare orde', waarover Hansebout 2014, art. 21 WIPR, aant. 2) en art. 6 van de Duitse EGBGB ('mit wesentlichen Grundsätzen des deutschen Rechts offensichtlich unvereinbar'). Anders: art. 17 van de Zwitserse IPRG ('mit dem schweizerischen Ordre public unvereinbar').

42. Zie bijv. Advies Staatscommissie IPR, nr. 79 (Parl. Gesch. Boek 10 BW, par. II.8.2). P. Vlas, IPR en BW (Mon. BW nr. A27), Deventer: Wolters Kluwer 2015, nr. 31, noemt de openbare orde een 'laatste redmiddel'; Asser/Vonken 10-I 2018/498 spreekt van een 'ultimum remedium'.

43. Illustratief zijn de voorbeelden gegeven door E. Frankenstein, Internationales Privatrecht. Erster Band, Berlijn: Rothschild 1926, p. 186-187. Jessurun d'Oliveira 1975, p. 242, nr. 3, schat de Nederlandse situatie mild in op 'soms', en meent (p. 250) dat 'in Nederland de slagboom van de openbare orde niet zo vaak neergehaald' wordt. Het is een interessante vraag of hij de situatie thans anders zou kwalificeren.

44. Asser/Vonken 10-I 2018/485, 499 en 518; Strikwerda \& Schaafsma $2019 / 131$. openbare orde. ${ }^{45}$ Toch zal het bloed zo nu en dan blijven kruipen waar het niet gaan kan; dat is eigen aan een vage norm, bij toepassing waarvan de rechter uit de aard der zaak beoordelingsruimte heeft. ${ }^{46}$

Art. 10:6 BW wordt geacht voort te bouwen op oudere rechtspraak over openbare orde als grens aan de toepassing van buitenlands recht. ${ }^{47}$ Volgens die rechtspraak kan onderscheid worden gemaakt tussen twee maatstaven. Volgens de eerste maatstaf (het 'buitengrenscriterium') kan een buitenlandse rechtsregel als zodanig onverenigbaar zijn met de Nederlandse internationale openbare orde. In dat geval is toepassing van die rechtsregel hoe dan ook onaanvaardbaar. ${ }^{48} \mathrm{Hier}$ ligt een analogie met het in paragraaf 4 geïntroduceerde begrip 'absolute openbare orde'.

De tweede maatstaf (het 'binnengrenscriterium') ziet op de gevolgen van toepassing van het buitenlandse recht in concreto. De rechter zal een buitenlandse rechtsregel die door de beugel van het buitengrenscriterium kan, niettemin buiten toepassing moeten laten als de concrete gevolgen waartoe die toepassing zou leiden, strijden met de Nederlandse internationale openbare orde. ${ }^{49}$ Dit is eerder het geval naarmate de casus een sterkere verbondenheid heeft met de Nederlandse rechtsorde. ${ }^{50}$ Dit zogenaamde betrokkenheidscriterium speelt zijn relativerende rol alleen bij het binnengrenscriterium, dat een analogie vertoont met het in paragraaf 4 geïntroduceerde begrip 'relatieve openbare orde'. Bij toepassing van het buitengrenscriterium is voor genoemde relativering geen plaats. ${ }^{51}$

Vonken verwerpt het onderscheid tussen beide maatstaven ten faveure van het binnengrenscriterium. ${ }^{52}$ Dit standpunt sluit aan bij het gegeven dat in het kader van art. 10:6 BW niet het buitenlandse recht als zodanig, maar de toepassing ervan voorwerp van toetsing is. ${ }^{53}$ Dit toetsingskader doet er evenwel niet aan af dat voor bepaalde regels geldt dat toepassing ervan

45. Zie bijv. Jessurun d'Oliveira 1975, p. 250

46. Door K. Teuben, Rechtersregelingen in het burgerlijk (proces)recht (diss. Leiden), Deventer: Kluwer 2004, par. 4.3.2, aangeduid met interpretatieruimte en gesteld tegenover beleidsruimte.

47. Zie bijv. Vlas 2015/31; Asser/Vonken 10-I 2018/494; Strikwerda \& Schaafsma 2019/132. De algemene bepalingen van titel 1 van Boek 10 BW vormen de codificatie van ongeschreven commuun internationaal privaatrecht; om die reden is er ook geen overgangsrecht opgenomen. Zie Kamerstukken II 2009/10, 32137, nr. 3, p. 95 (MvT). Ook uit de bespreking van het binnen- en buitengrenscriterium in de MvT op art. 10:6 BW (Parl. Gesch. Boek 10 BW, par. II.8.3) blijkt dat beoogd is dit onderscheid onder de vigeur van art. 10:6 BW te behouden.

48. Asser/Vonken 10-I 2018/494.

49. Zie met vermelding van rechtspraak Strikwerda \& Schaafsma 2019/132.

50. Jessurun d'Oliveira 1975, p. 243-244; Asser/Vonken 10-I 2018/492, uitgewerkt in nrs. 496-497; Strikwerda \& Schaafsma 2019/132, slot. Zie dienovereenkomstig over het Belgische recht Hansebout 2014, art. 21 WIPR, aant. 2.

51. Jessurun d'Oliveira 1975, p. 244; Strikwerda \& Schaafsma 2019/132.

52. Asser/Vonken 10-I 2018/492 en 495.

53. Wurmnest 2016, p. 319-320; Asser/Vonken 10-I 2018/491. Van een andere lijn lijkt te getuigen Advies Staatscommissie IPR, nr. 86-88 (Parl. Gesch. Boek 10 BW, par. II.8.2). 


\section{Maandblad Vermogensrecht}

steeds schending van de openbare orde oplevert. ${ }^{54}$ Dat is het geval bij (bepaalde) supranationale fundamentele rechten. ${ }^{55}$ Juist ten aanzien van die rechten wijst ook Vonken de aan het binnengrenscriterium verbonden relativering af. Vonken vermijdt strijd van dit standpunt met zijn verwerping van het buitengrenscriterium door de werking van supranationale fundamentele rechten in het kader van art. 10:6 BW buiten de Nederlandse internationale openbare orde te plaatsen. Ik kan moeilijk inzien dat die visie inhoudelijk afwijkt van of te prefereren valt boven het onderscheid tussen het binnen- en het buitengrenscriterium. ${ }^{56} \mathrm{Wat}$ mij betreft pleit voor het vasthouden aan laatstgenoemde tweedeling dat het antwoord op de vraag of een belang zo fundamenteel is dat een ermee strijdige regel steeds buiten toepassing moet blijven, niet zou moeten afhangen van de vraag of dit belang door nationale dan wel supranationale normen wordt gewaarborgd, maar van de aard en inhoud van het belang zelf.

De Nederlandse rechter zal het door het conflictenrecht aangewezen materiële recht toepassen in een procedure die verder wordt afgewikkeld op basis van zijn eigen procesrecht. Daarom is het internationaal erkende en verbreide onderscheid tussen materieelrechtelijke en procesrechtelijke openbare orde voor het conflictenrecht minder relevant. ${ }^{57}$ Hierna komt dit onderscheid nog aan de orde in het kader van erkenning en tenuitvoerlegging.

De inhoud van de Nederlandse internationale openbare orde wordt in de context van het conflictenrecht wel gedefinieerd als 'fundamentele waarden en beginselen van de Nederlandse rechtsorde'. ${ }^{58} \mathrm{Bij}$ een poging tot nadere duiding pleegt - op zichzelf met juistheid - voorop te worden gesteld dat het gaat om een vage, evoluerende notie, die niet in algemene bewoordingen kan worden gevangen, ${ }^{59}$ dat niet alle dwingend recht de openbare orde raakt, ${ }^{60}$ en dat de inhoud van het openbareordebegrip mede wordt bepaald door supranationaal recht. ${ }^{61}$ Veel concreter wordt het niet op conceptueel niveau; in de

54. Zie bijv. Strikwerda \& Schaafsma 2019/132.

55. Asser/Vonken 10-I 2018/493 en 517.

56. De door Asser/Vonken 10-I 2018/517 ontwikkelde redenering lijkt mij een petitio principii (en overigens ook te botsen met nr. 505). Deze redenering komt er immers op neer dat wegens de verwerping van het buitengrenscriterium de werking van fundamenteel supranationaal recht buiten de openbare orde moet worden geplaatst, omdat bij dat supranationale recht de aan het binnengrenscriterium klevende relativering niet aanvaardbaar is; het aanvaarden van het buitengrenscriterium lost dit probleem echter juist op.

57. Asser/Vonken 10-I 2018/503.

58. Vlas 2015/31. In soortgelijke bewoordingen: Asser/Vonken 10-I 2018/485 en 563; Strikwerda \& Schaafsma 2019/131; Advies Staatscommissie IPR, nr. 77 (Parl. Gesch. Boek 10 BW, par. II.8.2).

59. Zie bijv. Advies Staatscommissie IPR, nr. 80 (Parl. Gesch. Boek 10 BW, par. II.8.2); Vlas 2015/31; Asser/Vonken 10-I 2018/501 en (specifiek over het temporele aspect) 504 .

60. Zie bijv. Advies Staatscommissie IPR, nr. 81 (Parl. Gesch. Boek 10 BW, par. II.8.2).

61. Zie bijv. Advies Staatscommissie IPR, nr. 83 (Parl. Gesch. Boek 10 BW, par. II.8.2), toegespitst op Unierecht; Vlas 2015/31 noemt specifiek de mensenrechten, zoals onder meer verankerd in het Europees Verdrag voor de Rechten van de Mens. literatuur wordt na de bespreking van genoemde abstracte noties doorgestapt naar het bespreken van voorbeelden. In het bijzonder wordt er geen 'bewijs' geleverd voor het wel unisono aanvaarde differentiatieaxioma, dat, zoals in paragraaf 2 aan de orde kwam, inhoudt dat de internationale openbare orde een (nog) aanzienlijk terughoudender begrip is dan de nationale openbare orde. Is aanvaarding van deze gedachte echt nodig om tot de gewenste terughoudendheid te komen?

Aan de hand van het volgende voorbeeld hoop ik te verhelderen dat dit niet zo is. Een overeenkomst kan naar toepasselijk buitenlands recht geldig zijn, terwijl deze naar Nederlands recht nietig zou zijn wegens strijd met de openbare orde. Als die geldigheid naar toepasselijk buitenlands recht van de desbetreffende overeenkomst door de openbareordebeugel van art. 21 Rome I-Verordening kan, dwingt dat niet tot de conclusie dat die drempel lager is dan die van art. 3:40 lid 1 BW. Volgens mij kan een dergelijk geval beter aldus worden verklaard dat het gelden van een buitenlands vonnis waarin geldigheid van een overeenkomst wordt aanvaard die naar Nederlands recht in strijd zou zijn met de openbare orde, niet zelf in strijd hoeft te zijn met de openbare orde, omdat gelding van een vonnis moet worden onderscheiden van gelding van de erin aanvaarde overeenkomst.

Dat kostenverhaal door de overheid een wettelijke grondslag behoeft, kan in een nationale situatie tot nietigheid op grond van art. 3:40 lid $1 \mathrm{BW}$ leiden, ${ }^{62}$ maar zal dat in een door buitenlands recht beheerste verhouding met een overheid niet hoeven te doen op grond van art. 10:6 BW. Dat ligt, zo meen ik, niet aan een afwijkend, meer terughoudend openbareordebegrip, maar dat komt omdat de (Nederlandse internationale) openbare orde niet per se wordt geraakt door een rechterlijke uitspraak die in dergelijk kostenverhaal voorziet. Bij een overeenkomst tot slavernij ligt dit uiteraard anders: hier wordt het buitengrenscriterium geraakt en betreft het een kwestie van absolute openbare orde.

Kortom: als het buitengrenscriterium of, met andere woorden, de absolute openbare orde in het geding is, hebben we te maken met een simpele casus (omdat er evident sprake is van strijd met het buitengrenscriterium) en werkt de openbare orde allesverzengend. In zoverre staat de uniformiteit van het openbareordebegrip ook buiten kijf. Gaat het om het binnengrenscriterium of relatieve openbare orde, dan ligt de zaak genuanceerd. Dit heeft in mijn visie niet te maken met een contextgebonden openbareordebegrip of een extra terughoudend internationale-openbareordebegrip, maar met het gegeven dat toepassing van buitenlands recht dat 'slechts' raakt aan de Nederlandse relatieve openbare orde doordat het door het buitenlandse recht toegelaten rechtsgevolg er naar Nederlands recht niet zou zijn, niet zonder meer onaanvaardbaar is. Het via een Nederlands vonnis tot gelding brengen van dat rechts-

62. Zie bijv. HR 5 december 2014, ECLI:NL:HR:2014:3532, NJ 2016/159 m.nt. S.D. Lindenbergh (Michielse/Gem. Reusel-De Mierden), r.o. 3.4.2. 
gevolg naar buitenlands recht is dus niet zonder meer in strijd met de openbare orde.

\section{Grenzen aan erkenning en tenuitvoerlegging van buitenlandse uitspraken: Brussel I bis}

De Brussel I bis-Verordening gaat uit van automatische erkenning en tenuitvoerlegging zonder verlofvereiste van buitenlandse uitspraken waarop de verordening van toepassing is (art. 36 lid 1 en 39 Brussel I bis-Verordening). ${ }^{63}$ Op grond van art. 45 lid 1 sub a (jo. art. 46) Brussel I bis-Verordening kan een belanghebbende (respectievelijk de geëxecuteerde) zich tegen erkenning (respectievelijk tenuitvoerlegging ${ }^{64}$ ) verzetten wegens kennelijke strijd met de openbare orde van de aangezochte lidstaat. De voor de uitleg van dit openbareordebegrip maatgevende overwegingen zijn onder meer te vinden in het arrest Trade Agency/Seramico. ${ }^{65} \mathrm{Ik}$ vat de vooropstellingen van het Hof van Justitie van de EU (hierna: HvJ EU) samen:

1. Vrij verkeer van uitspraken is uitgangspunt, zodat de openbareorde-exceptie slechts in uitzonderlijke gevallen mag worden gehanteerd (r.o. 48).

2. De lidstaten bepalen de inhoud van hun openbare orde overeenkomstig hun nationale inzichten, ${ }^{66}$ maar de afbakening van dit begrip is een kwestie van uitlegging van de verordening, waardoor het $\mathrm{HvJ} \mathrm{EU}$ aan grensbewaking doet (r.o. 49).

3. Die grensbewaking moet voorkomen dat uitspraken uit andere lidstaten aan het nationale recht of inhoudelijk worden getoetst (r.o. 50).

\section{Vervolgens komt het HvJ EU tot de kern (r.o. 51):}

'Er kan dus enkel een beroep worden gedaan op de openbare-ordeclausule (...) indien de erkenning of de tenuitvoerlegging van de in een andere lidstaat gegeven beslissing op onaanvaardbare wijze zou indruisen tegen de rechtsorde van de aangezochte lidstaat doordat zij inbreuk zou maken op een fundamenteel beginsel. De inbreuk zou moeten bestaan in kennelijke schending van een rechtsregel die in de rechtsorde van de aangezochte lidstaat van essentieel belang wordt geacht, of van een in die rechtsorde als fundamenteel erkend recht (...).'

63. Zie bijv. Strikwerda \& Schaafsma 2019/266-267.

64. Object van toetsing is dus de erkenning of tenuitvoerlegging, en niet de uitspraak zelf; zie bijv. Vlas, in: GS Burgerlijke rechtsvordering, art. 45 Brussel I bis-Verordening, aant. 4.

65. HvJ EU 6 september 2012, C-519/10, ECLI:EU:C:2012:531, NJ 2013/79 m.nt. L. Strikwerda (Trade Agency/Seramico), met verwijzingen naar eerdere rechtspraak. Dit arrest is weliswaar onder de Brussel IVerordening gewezen, maar de onder de Brussel I-Verordening gewezen rechtspraak is in beginsel ook van belang voor de uitleg van de Brussel I bis-Verordening. Zie bijv. Schaafsma, in: T\&C Rv, Brussel I bis-Verordening, Inleidende opmerkingen, aant. 7c.

66. Ook hier weer geldt dat supranationaal recht in zoverre voor uniformering zorgt. Zie bijv. HvJ EU 16 juli 2015, C-681/13, ECLI:EU:C: 2015:471, NJ 2017/32 m.nt. L. Strikwerda (Diageo Brands/Simiramida), r.o. 50 .
Ook in dit kader wordt in de literatuur zonder veel omhaal het uitgangspunt aanvaard dat niet alle nationale normen van openbare orde voldoende fundamenteel zijn om onderdeel uit te maken van de internationale openbare orde. Zo meent Hazelhorst dat de internationale openbare orde (door haar aangeduid als 'external public policy') 'much narrower' zou zijn dan de nationale openbare orde. ${ }^{67} \mathrm{Zij}$ verwijst naar Corthaut, ${ }^{68}$ die de internationale openbare orde 'far more limited' noemt dan de nationale openbare orde, en naar Van Hoek, die in haar bespreking van het arrest Krombacher/ Bamberski ${ }^{69}$ stelt:

'In private international law in general, "international public policy" is a much more limited notion than "domestic public policy". ${ }^{70}$

Geen van deze auteurs geeft een inhoudelijke onderbouwing van deze aanvaarding van het differentiatieaxioma. ${ }^{71}$ Ook hier meen ik aan de hand van voorbeelden te kunnen laten zien dat het mogelijk is uit te gaan van een uniform openbareordebegrip en dat het niet nodig is te differentiëren tussen nationale en internationale openbare orde. Zo kan een buitenlandse uitspraak, gewezen naar toepasselijk Nederlands recht, rechtsgevolg toekennen aan een overeenkomst die naar Nederlands recht nietig is wegens strijd met de openbare orde. Als honorering van die rechtsgevolgen in de buitenlandse uitspraak door de openbareordebeugel van art. 45 lid 1 sub a (jo. art. 46) Brussel I bis-Verordening kan, dwingt dit niet tot de conclusie dat die drempel lager is dan die van art. 3:40 lid 1 BW. Beter kan het aldus worden beschouwd dat de bezwaarlijkheid van het toekennen van werking aan die buitenlandse uitspraak zich laat relativeren. Dat kostenverhaal door de overheid een wettelijke grondslag behoeft, kan tot nietigheid op grond van art. 3:40 lid $1 \mathrm{BW}$ leiden, ${ }^{72}$ maar dat betekent niet dat honorering van zulk contractueel kostenverhaal in een buitenlandse uitspraak als zodanig in strijd is met de openbare orde. Dat ligt niet aan een afwijkend, meer terughoudend openbareordebegrip, maar dat komt omdat de (Nederlandse internationale) openbare orde niet in de weg staat aan gelding en afdwingbaarheid van de buitenlandse uitspraak waarin dat kostenverhaal is gehonoreerd. De paradox in de toetsingsresultaten wordt, met

67. M. Hazelhorst, Free Movement of Civil Judgments in the European Union and the Right to a Fair Trial (diss. Rotterdam), Den Haag: Asser Press 2017, p. 67 en 295.

68. Corthaut 2012, nr. I-26.

69. HvJ EG 28 maart 2000, C-7/98, ECLI:EU:C:2000:164, NJ 2003/626 m.nt. P. Vlas (Krombach/Bamberski).

70. A.H. van Hoek, Case C-7/98, D. Krombach v. A. Bamberski, Judgment of the Full Court of 28 March 2000. [2000] ECR I-1395, Common Market Law Review (28) 2001, p. 1018.

71. Hoewel ik mij bewust ben van de zwakte van argumenten $e$ silentio, merk ik op dat Vlas in zijn bespreking van art. 45 lid 1 sub a Brussel I bis-Verordening (in: GS Burgerlijke rechtsvordering, art. 45 Brussel I bis-Verordening, aant. 5) het openbareordebegrip van die bepaling niet afzet tegen het nationale openbareordebegrip, net zomin als Strikwerda \& Schaafsma 2019/269, of Krzemiński, in: T\&C Rv, Brussel I bis-Verordening, art. 45 , aant $2 \mathrm{a}$.

72. Zie bijv. HR 5 december 2014, ECLI:NL:HR:2014:3532, NJ 2016/159 m.nt. S.D. Lindenbergh (Michielse/Gem. Reusel-De Mierden), r.o. 3.4.2. 
andere woorden, niet veroorzaakt doordat de maatstaven verschillen, maar doordat de toetsingsobjecten uiteenlopen: gelding van een overeenkomst versus gelding van een buitenlandse rechterlijke uitspraak. Ook hier weer ligt dit anders bij een overeenkomst tot slavernij: dit betreft een kwestie van absolute openbare orde, die (dus) voor relativering geen ruimte laat.

Ook hier zou ik dus het differentiatieaxioma willen verwerpen. De gronden die ik hiervoor aanvoer, komen overeen met hetgeen ik ten aanzien van het contextaxioma bij nationaalrechtelijke openbareordetoepassingen (zie par. 3 en 4) en ten aanzien van het differentiatieaxioma bij de toepassing van buitenlands recht (zie par. 5) heb uiteengezet. Ook in het kader van art. 45 lid 1 sub a (jo. art. 46) Brussel I bis-Verordening zie ik geen aanwijzingen voor de stelling dat de inhoud van de internationale openbare orde verschilt van de openbare orde in de nationaalrechtelijke context van onder meer art. 3:40 BW. Ook hier geldt dat er (schijnbare) verschillen kunnen zijn, doordat (ogenschijnlijk) vergelijkbare casus vanuit de ene dan wel de andere invalshoek anders kunnen uitpakken indien de relevante normen 'slechts' de relatieve openbare orde betreffen. Als de casus de absolute openbare orde raakt, ligt het eenvoudig: gelding van een uitspraak waarvan de inhoud strijdt met zodanig fundamentele uitgangspunten is dan ook onaanvaardbaar.

\section{Grenzen aan erkenning en tenuitvoerlegging van buitenlandse uitspraken en arbitrale vonnissen: overige regelingen}

Art. 985 e.v. Rv bieden een regeling voor de uitvoerbaarverklaring van buitenlandse uitspraken die krachtens wet of verdrag in Nederland uitvoerbaar zijn. Deze regeling houdt in dat rechterlijk verlof ('exequatur') is vereist. Via art. $1075 \mathrm{Rv}$ is de regeling van overeenkomstige toepassing op de erkenning en tenuitvoerlegging van buitenlandse arbitrale vonnissen waarop een erkennings- en tenuitvoerleggingsverdrag van toepassing is. De regeling heeft een supplementair karakter: voor zover (de uitvoeringsregeling van) een verdrag een eigen uitvoerbaarheidsregeling kent, gaat deze voor (art. 992 en 1075 lid 2 Rv).

De regeling van art. 985 e.v. Rv bevat geen weigeringsgronden; in hoeverre verdragen weigeringsgronden kennen, loopt sterk uiteen. Uit de rechtspraak volgt dat steeds kan worden teruggevallen op een openbareorde-exceptie. ${ }^{73}$ Voor erkenning en tenuitvoerlegging van arbitrale vonnissen is het Verdrag van New York ${ }^{74}$ van grote betekenis. Dat verdrag kent een eigen openbareorde-exceptie: art. V lid 2 sub b bepaalt dat erkenning of verlof tot tenuitvoerlegging mag worden geweigerd,

73. HR 10 september 1999, ECLI:NL:HR:1999:ZC9662, NJ 2001/41 m.nt. P. Vlas (Triumph/Cabana c.s.), r.o. 3.13. Zie ook de conclusie van A-G Strikwerda, nr. 23 met nadere verwijzingen, en de noot van Vlas, nr. 3-4, eveneens met nadere verwijzingen.

74. Trb. 1958, 145 (Engelse en Franse authentieke teksten) en Trb. 1959, 58 (Nederlandse vertaling). indien ' $[\mathrm{t}]$ he recognition or enforcement of the award would be contrary to the public policy of that country'.

Een buitenlands arbitraal vonnis kan ook buiten verdrag of als een toepasselijk verdrag het toelaat worden erkend en van tenuitvoerleggingsverlof worden voorzien op grond van art. 1076 Rv. Een dergelijk arbitraal vonnis komt niet in aanmerking voor erkenning en tenuitvoerlegging indien dit strijdig zou zijn met de openbare orde (art. 1076 lid 1 sub B Rv).

Art. $431 \mathrm{Rv}$ bepaalt dat buitenlandse rechterlijke uitspraken buiten verdrag niet voor tenuitvoerlegging in Nederland in aanmerking komen (lid 1), en dat een retrial nodig is (lid 2). In het Gazprombank-arrest heeft de Hoge Raad in het voetspoor van eerdere rechtspraak verduidelijkt dat daarbij onder voorwaarden (de zogenaamde 'Gazprombank-criteria') gezag kan worden toegekend aan een buitenlandse uitspraak. Strekt een vordering op de voet van art. 431 lid $2 \mathrm{Rv}$ tot veroordeling tot hetgeen waartoe de wederpartij in de buitenlandse beslissing is veroordeeld, en is aan de Gazprombank-criteria voldaan, dan dient de rechter de gebondenheid van partijen aan die beslissing tot uitgangspunt te nemen, en is de vordering in beginsel toewijsbaar. ${ }^{75}$ Een van de criteria houdt in dat de erkenning van de buitenlandse beslissing niet in strijd is met de Nederlandse openbare orde. Een van de andere criteria houdt in dat de buitenlandse beslissing tot stand moet zijn gekomen in een gerechtelijke procedure die voldoet aan de eisen van behoorlijke en met voldoende waarborgen omklede rechtspleging. ${ }^{76}$ Dit laatste criterium kan worden gezien als een species van het openbareordecriterium. Het afzonderlijk benoemen van de 'processuele openbare orde' naast de 'materiele openbare orde' strookt met hetgeen internationaal wordt aanvaard en gebruikelijk is. ${ }^{77}$ De erkenningsrechter dient zich verre te houden van herbeoordeling (révision au fond $)^{78}$ en dient (dus) marginaal te toetsen.

De Hoge Raad is in het arrest Promneftstroy c.s./Yukos Finance c.s. ingegaan op de strekking van de openbareordedrempel in een overweging die ziet op zowel de processuele als de materiële openbare orde: ${ }^{79}$

'Deze voorwaarden beogen te voorkomen dat in de Nederlandse rechtsorde een buitenlandse rechterlijke beslissing

75. HR 26 september 2014, ECLI:NL:HR:2014:2838, NJ 2015/478 m.nt. Th.M. de Boer (Gazprombank/Bensadon), r.o. 3.6.5.

76. HR 26 september 2014, ECLI:NL:HR:2014:2838, NJ 2015/478 m.nt. Th.M. de Boer (Gazprombank/Bensadon), r.o. 3.6.4; HR 17 juli 2021, ECLI:NL:HR:2021:1170 (ABA/Enel c.s.), r.o. 3.2.2.

77. Zie bijv. Prütting \& Gehrlein/Völzmann-Stickelbrock 2019, §328 ZPO, Rn. 24; Beck OK/Bach 2020, $\$ 328$ ZPO, Rn. 39; Musielak/Voit/Stadler 2020, \$328 ZPO, Rn. 25-25a.

78. In deze zin: HR 18 januari 2019, ECLI:NL:HR:2019:54, NJ 2019/364 m.nt. Th.M. de Boer (Promneftstroy c.s./Yukos Finance c.s.), r.o. 4.1.4. Zie bijv. ook Zöller/Geimer 2018, \$328 ZPO, Rn. 208, en art. $25 \$ 2$ WIPR: 'In geen geval mag de buitenlandse rechterlijke beslissing ten gronde worden herzien.'

79. HR 18 januari 2019, ECLI:NL:HR:2019:54, NJ 2019/364 m.nt. Th.M. de Boer (Promneftstroy c.s./Yukos Finance c.s.), r.o. 4.1.3. 


\section{Maandblad}

tot gelding komt die naar haar totstandkoming of haar inhoud in strijd is met beginselen en waarden die in de Nederlandse rechtsorde als fundamenteel worden aangemerkt.'

In deze overweging over de strekking van de openbareordedrempel benoemt de Hoge Raad zowel het toetsingsobject als de maatstaf waaraan wordt getoetst. De maatstaf is helder: dat zijn de beginselen en waarden die in de Nederlandse rechtsorde als fundamenteel worden aangemerkt. Ik zie niet in dat deze maatstaf als erkenningsdrempel als zodanig zinvol kan worden onderscheiden van de openbareordecriteria van art. 10:6 BW of die van de hiervoor besproken verordeningen. De aanduiding van het toetsingsobject is minder ondubbelzinnig: moet het accent worden gelegd op de gelding van de rechterlijke beslissing, of op de totstandkoming en inhoud daarvan? Ik zou hier een soortgelijke zienswijze willen verdedigen als ten aanzien van art. 1065 lid 1 sub e $\mathrm{Rv}$ (zie hiervoor par. 4). Beslissend is of gelding van de buitenlandse beslissing de openbare orde raakt. Wordt in de buitenlandse beslissing Nederlands recht toegepast en wordt daarbij recht van openbare orde miskend, dan is gelding van die uitspraak daarom nog niet per se onaanvaardbaar. Dat is alleen zo als sprake is van miskenning van regels van absolute openbare orde (zie weer het voorbeeld van een overeenkomst die strekt tot slavernij). Miskenning in de buitenlandse uitspraak van de Nederlandsrechtelijke regels omtrent kostenverhaal door de overheid, die weliswaar naar ons recht van openbare orde zijn, betekent nog niet dat gelding van die uitspraak in strijd is met de openbare orde (de uitwerking van dit punt in par. 4 is hier mutatis mutandis van toepassing).

In zijn vervolg op de geciteerde overweging uit het arrest Promneftstroy c.s./Yukos Finance c.s. zet de Hoge Raad de openbareordedrempel van de Gazprombank-criteria af tegen de openbareordedrempel van (onder meer) de Brussel I bisVerordening: ${ }^{80}$

' $\mathrm{Bij}$ de beoordeling of aan deze voorwaarden is voldaan, geldt niet het beginsel van wederzijds vertrouwen in de rechtsbedeling van de staat van herkomst, dat ten grondslag ligt aan internationale regelingen over erkenning en tenuitvoerlegging van buitenlandse beslissingen.'

Betekent dit nu dat de openbareordemaatstaf van de Gazprombank-criteria eerder tot erkenningsweigering leidt dan die van art. 45 lid 1 sub a Brussel I bis-Verordening? Het gegeven dat de uitspraak tegen erkenning waarvan wordt opgekomen uit een EU-lidstaat afkomstig is, pleit wegens het beginsel van wederzijds vertrouwen in algemene zin voor erkenning, en dus ertegen dat de openbare orde aan erkenning in de weg staat. Dat betekent evenwel nog niet per se dat het om een andere openbareordemaatstaf gaat; beter kan het aldus worden beschouwd dat het gezichtspunt 'wederzijds vertrouwen'

80. HR 18 januari 2019, ECLI:NL:HR:2019:54, NJ 2019/364 m.nt. Th.M de Boer (Promneftstroy c.s./Yukos Finance c.s.), r.o. 4.1.3. gewicht in de schaal legt bij de invulling van de openbareordemaatstaf. Dit betekent naar mijn mening evenwel niet dat die maatstaf als zodanig afwijkt van de openbareordemaatstaf van (bijvoorbeeld) de Gazprombank-criteria. Dat ook laatstgenoemde maatstaf met uiterste terughoudendheid moet worden toegepast, vindt mede steun in rechtsvergelijkende gegevens. ${ }^{81}$

In de zaak Promneftstroy c.s./Yukos Finance c.s. was onder meer aan de orde of de openbare orde in het kader van de Gazprombank-criteria een 'afgezwakte werking' toekomt. De Hoge Raad houdt zich op de vlakte. Hij interpreteert het oordeel van het hof over de erkenning van het litigieuze faillissementsvonnis aldus, dat daarin ${ }^{82}$

'(...) ligt besloten dat het daarbij gaat om strijd met beginselen en waarden die in de Nederlandse rechtsorde als fundamenteel worden aangemerkt en dat daarmee de grenzen zijn overschreden waarbinnen nog rechtsgevolg kan worden verbonden aan het faillissementsvonnis. Het hof heeft (...) overwogen dat dit oordeel meebrengt dat rechtshandelingen die ter uitvoering van dat vonnis of op basis van dat vonnis in Nederland zijn verricht, zonder meer ongeldig zijn, ongeacht de gevolgen daarvan. Dit oordeel getuigt niet van een onjuiste rechtsopvatting en is ook niet onvoldoende gemotiveerd.'

Oftewel: wat er ook zij van de mogelijke relativering van de openbareordetoetsing, in dit geval heeft het hof voor een dergelijke relativering hoe dan ook geen aanleiding hoeven zien. $\mathrm{Bij}$ dit oordeel speelt de aan het hof toekomende beoordelingsruimte een rol. Dat het hof in deze zaak niet hoefde te relativeren, betekent (dus) niet dat er voor relativering in algemene zin geen ruimte is. Het ligt, mede vanuit het oogpunt van rechtseenheid, ${ }^{83}$ voor de hand om ook (zie over het conflictenrecht par. 5) ten aanzien van de erkenning van buitenlandse uitspraken onderscheid te maken tussen een buiten- en een

81. Zie over de wettelijke maatstaf van $₫ 328$ IV ZPO (erkenning leidt tot een resultaat dat '(...) mit wesentlichen Grundsätzen des deutschen Rechts offensichtlich unvereinbar ist') bijv. Stein/Jonas/Roth 2015, $\$ 328$ ZPO, Rn. 112 ('nur eklatante Mängel'); Rosenberg/Schwab/Gottwald 2018, § 158, Rn. 49 ('untragbar'); Zöller/Geimer 2018, §328 ZPO, Rn. 210 ('nur in ganz krassen Fällen'); Prütting \& Gehrlein/VölzmannStickelbrock 2019, \$328 ZPO, Rn. 23 (eveneens 'untragbar'); Beck OK/ Bach 2020, 328 ZPO, Rn. 38 ('äußerst restriktiv’). Zie over de wettelijke maatstaf van art. $25 \$ 1$ onder 1 WIPR H. Storme, art. 25 WIPR, aant. 2.1, in: I. Couwenberg e.a. (red.), Duiding internationaal privaatrecht, Gent: Larcier 2014.

82. HR 18 januari 2019, ECLI:NL:HR:2019:54, NJ 2019/364 m.nt. Th.M. de Boer (Promneftstroy c.s./Yukos Finance c.s.), r.o. 4.5.3.

83. In deze richting ook Asser/Vonken 10-I 2018/486, slot. 
binnengrenscriterium, ${ }^{84}$ ofwel tussen absolute en relatieve openbare orde.

Op grond van het voorafgaande zou ik willen volhouden dat ook de bij erkenning van rechterlijke en arbitrale uitspraken toe te passen openbareordemaatstaf niet afwijkt van de 'gewone' nationale openbare orde (waarover par. 3 en 4), en dat een voor wat betreft het openbareordebegrip schijnbaar verschil in uitkomsten afhangt van onderscheid in toetsingsobject (om bij het kenmerkende voorbeeld te blijven: gelding van een overeenkomst versus gelding van een uitspraak waarin die overeenkomst is beoordeeld), en niet van inconsistentie of meerduidigheid in het openbareordebegrip zelf. Om nog een voorbeeld te geven: erkenning van een buitenlands arbitraal vonnis dat (in overeenstemming met het toepasselijke recht) is gewezen door twee arbiters is niet in strijd met de internationale openbare orde, ${ }^{85}$ terwijl een Nederlands arbitraal vonnis dat is gewezen door twee arbiters vernietigbaar is op grond van art. 1065 lid 1 sub b (een regel van openbare orde) en e Rv. ${ }^{86}$ Dat verschil in uitkomst komt niet door een afwijkende gestrengheid van de toegepaste openbareordemaatstaven, maar ligt aan het feit dat geldigheid van een Nederlands arbitraal vonnis een ander toetsingsobject is dan erkenning van een (naar het toepasselijke recht geldig) buitenlands vonnis. Het wijzen van een arbitraal vonnis door twee arbiters is, in de door mij gebruikte terminologie, geen kwestie van absolute maar van relatieve openbare orde; deze 'fout' werkt dus niet per se allesverzengend, en het in Nederland gelden van een buitenlands arbitraal vonnis dat door twee arbiters is gewezen, is dus niet per se in strijd met onze openbare orde.

\section{Evaluatie}

In het voorafgaande heb ik tegenspraak geboden aan twee veelgehoorde uitgangspunten. Het eerste uitgangspunt is dat openbare orde een contextgebonden begrip is, waarvan de inhoud per context verschilt. Het tweede uitgangspunt is dat onderscheid moet worden gemaakt tussen het openbareordebegrip van het nationale recht en het (nóg terughoudender in te vullen) openbareordebegrip in het internationaal privaatrecht. Ik maakte een gang langs de voor de nationale en internationale procespraktijk belangrijkste toepassingen van het openbareordebegrip.

Mijn onderzoek brengt mij tot het poneren van twee alternatieve uitgangspunten. Het eerste alternatieve uitgangspunt is

84. Aldus ook A-G Vlas met nadere verwijzingen in par. 3.48 van zijn conclusie (ECLI:NL:PHR:2018:1017) voor HR 18 januari 2019, ECLI:NL:HR:2019:54, NJ 2019/364 m.nt. Th.M. de Boer (Promneftstroy c.s./Yukos Finance c.s.). Naar Duits recht is heersende leer dat de openbareordetoets op grond van dit effet atténué in het kader van de erkenning nóg terughoudender dient te zijn dan in het conflictenrecht. Zie bijv. Prütting \& Gehrlein/Völzmann-Stickelbrock 2019, §328 ZPO, Rn. 23; Beck OK/Bach 2020, $\$ 328$ ZPO, Rn. 39 (zie over relativering Rn. 42). In België is heersende leer dat het effet atténué ten aanzien van conflictenrecht en erkenning in gelijke mate opgeld doet. Zie Storme 2014, art. 25 WIPR, aant. 2.1.

85. Meijer, in: T\&C Rv, art. 1076, aant. 2 i.

86. Meijer, in: T\&C Rv, art. 1065, aant. 3 b. dat de inhoud van het openbareordebegrip consistent is, en dat schijnbare inconsistenties het resultaat zijn van verschillen in toetsingsobject. Zo is verdedigbaar dat een arbitraal vonnis waarin een vordering wordt toegewezen die steunt op een overeenkomst die nietig is wegens strijd met de openbare orde, niet steeds reeds om die reden vernietigbaar is wegens strijd met de openbare orde. Dit komt niet omdat art. 1065 lid 1 sub e $\mathrm{Rv}$ een terughoudender openbareordebegrip kent dan art. 3:40 lid $1 \mathrm{BW}$, maar doordat het toetsingsobject verschilt: gelding van een overeenkomst versus gelding van een arbitraal vonnis. Voor deze relativering van openbare orde is geen ruimte bij kwesties van absolute openbare orde. Aldus valt een tweedeling waar te nemen binnen het openbareordebegrip, die op een deelterrein al bekend is als de tweedeling tussen binnengrens- en buitengrenscriterium in het conflictenrecht. Ter voorkoming van misverstand: tweedeling is niet een 'hernoeming' van het contextaxioma, maar is onderdeel van een daarvan afwijkende verklaring van schijnbaar onverenigbare uitkomsten bij toetsing aan de openbare orde. De fundamenten van die verklaring zijn dat het openbareordebegrip uniform is, en dat voor een goed begrip van de toepassing ervan met name van belang is in het oog te houden wat er aan de openbare orde wordt getoetst, en welk rechtsgevolg aan die toetsing verbonden is.

Het tweede alternatieve uitgangspunt, dat op het eerste voortbouwt, is dat er evenmin inhoudelijk verschil is tussen het nationale en het (Nederlandse) internationale openbareordebegrip. Het is veeleer zo dat internationale aspecten kunnen bijdragen aan een ontkennende beantwoording van de vraag of sprake is van strijd met de openbare orde, dan dat de 'internationale openbare orde' als maatstaf nóg terughoudender is dan die van de openbare orde in nationaal verband. Als een arbitraal vonnis dat naar de maatstaf van art. 1065 lid 1 sub e Rv vernietigbaar zou zijn, naar de maatstaf van art. 1076 lid 1 sub $\mathrm{B} R v$ voor erkenning in aanmerking komt, ligt dat in de hier verdedigde visie niet aan het onderscheid in maatstaf maar aan het gegeven dat de openbare orde zich niet per se verzet tegen een buitenlands arbitraal vonnis dat, als het een Nederlands arbitraal vonnis zou zijn geweest, niet door de beugel van de openbare orde zou kunnen. Ook in zoverre is sprake van twee maten van openbare orde: relatieve openbare orde, waarvan de rechtsgevolgen zich laten relativeren, en absolute openbare orde. Wanneer deze laatste categorie in het geding is, wordt aan daardoor geraakte rechtshandelingen en uitspraken in alle opzichten rechtsgevolg onthouden. 